\title{
Factors Limiting Knowledge Management among Construction Small and Medium Enterprises
}

\author{
Samuel I. Egwunatum ${ }^{1}$ and Justina C. Oboreh ${ }^{2}$ \\ ${ }^{1}$ Lecturer, Department of Quantity Surveying, Federal University of Technology, Owerri, Imo State, Nigeria. \\ Email: samuelegwunatum1@gmail.com (corresponding author). \\ ${ }^{2}$ Lecturer, Department of Business Administration \& Marketing, Delta State University, Abraka, Nigeria. \\ Email: jcoboreh@delsu.edu.ng
}

Project Management

Received February 19, 2021; revised June 10, 2021; accepted June 19, 2021

Available online September 13, 2021

\begin{abstract}
The construction industries of both developed and developing countries are dominated by construction small and medium enterprises (SMEs). The industry is project-based and requires knowledge workers for performance. Construction SMEs contribute significantly to employment generation, economic growth and prosperity, innovation diffusion, among others. They, however, are faced with poor productivity and performance, especially in the area of time, cost, quality and safety. This is hinged on their rigidity and inflexibility to the adoption of modern management techniques, amidst other external environmental constraints. Knowledge is a vital asset of organisations and knowledge management $(\mathrm{KM})$ is a critical strategic and tactical management tool for improving organisations productivity, competitiveness and survival. This study aims to assess the factors limiting a full-scale implementation of effective KM practices among construction SMEs, especially on construction projects in the south-south region of Nigeria. This study leverages an electronic questionnaire and snowballs sampling technique to gather data from the SMEs' construction professional employees in the study. The collected data were analysed using factor analysis and the Mann-Whitney U test. The study found that technology-related barriers, cultural and management barriers, motivation and time barriers, awareness and communication barriers, and insecurity barriers, were the major cluster of factors limiting effective KM implementation by SMEs. Furthermore, no significant statistical difference in the perception of the small and medium-sized organisations was also found. It is recommended that adequate government and top management supports are needed to overcome the barriers and entrench KM practices as the key tactical and strategic tool for improving productivity and performance and ensuring the sustenance and survival of the construction SMEs.
\end{abstract}

Keywords: Knowledge management, construction project, construction small and medium enterprises, knowledge management barriers, Nigeria.

Copyright $\odot$ Journal of Engineering, Project, and Production Management (EPPM-Journal).

DOI 10.32738/JEPPM-2022-0003

\section{Introduction}

The construction industry of every nation is instrumental to economic growth and infrastructural development. Adegboyega et al. (2019) state that the activities of the construction industry act as a catalyst and stimulant to economic sustenance and infrastructural provisions in both advanced and emerging countries of the world. In this era, the industry is, however, tensed as a result of the high level of competition triggered by the fast technological advancement and innovative and modern construction techniques (Onyeagam et al., 2020; Suhana et al., 2020). According to Gilson and Shalley (2004), organisations have devised means of surviving the pressure of competition of the industry by frequently looking for innovative ways of ensuring unbroken supply chain networks. If an organisation is to be competitive, it must adopt a more sustainable and responsive strategic and tactical management tool. Zerbino et al. (2018) and Chen and Fong (2015) posit that KM is now a major strategic factor for surviving the current industrial environment.

According to Santoso (2020), KM is now a critical factor for ensuring the improvement and sustainable productivity of construction organisations. Koochakzadeh and Behzadi (2019) state that knowledge help in creating, developing and maintaining a sustainable competitive position of organisations in both the developed and emerging economies of the world. In the same vein, Yip (2011) posits that one of the commonly favoured concepts is $\mathrm{KM}$ Brown et al. (2003) posit that $\mathrm{KM}$ enables the creation of a workplace environment that enhances and supports teamwork, collaboration, and continuous learning and sharing of knowledge. However, Robinson et al. (2005) 
contend that the construction industry is principally project-based, and KM has remained a persistent challenge in the sector. Siemieniuch and Sinclair (1999) averred that there is an increased risk of reinventing the wheel, wastage, and diminished performance of the project; due to the failure of firms to capture and share project knowledge. One of the key categories of very important actors in the construction sector is the small and medium enterprises (SMEs). The construction industry of every nation is dominated by construction SMEs (Unnikrishnan et al., 2015; Eze et al., 2020). The SMEs compete in the same industry with their larger counterpart, and surviving in such a highly competitive environment requires innovation and adoption of modern and innovative management techniques. According to Centobelli et al. (2019), a critical task for SMEs is managing the KM processes for better positioning in the construction market. SMEs have remained unyielding to the update and adoption of innovative management approaches and modern technologies, especially in developing countries of Africa.

Nigeria is a developing country with construction industry in which the practice of KM practice is still in its infancy (Onyeagam et al., 2020), and is poorly practised, and not given adequate attention. This, according to Alhaji et al. (2013a), is responsible for the poor performance and productivity records of construction projects in the country. A frequent problem in the construction industry in developing countries like Nigeria, has remained schedule and cost overruns, low quality and productivity and lack of satisfaction for clients (Ademeso and Windapo, 2008). Alhaji et al. (2013a) posit that there is a very high level of information lost, distortions; because of the lack of dedication and low innovation of construction organisations. KM practices boost productivity by increasing workers' access to information, experience, solutions and best practices, thus, there preventing reinventing the wheel. Furthermore, knowledge loss due to employees leaving organisations are limited (Roner, 2019). It then follows that the ability of construction SMEs to have their productivity improved and compete favorably is hinged on how well they can create and leverage effective KM practices.

There are limited studies on KM in Nigeria. The few available studies on KM related studies in Nigeria have been centred on; mode of knowledge sharing practices in construction firms (Alhaji et al., 2013a), KM practices relationship with the survival and sustenance of construction firms (Onyeagam et al., 2020), project KM practices of civil engineering construction firms (Alhaji et al., 2013b), KM critical success factors in the construction industry (Idris and Kolawole, 2016), and KM practices among construction professionals (Oke et al., 2013), KM practices in telecommunication industry (Suraj and Ajiferuke, 2013), Nigerian universities and other tertiary institutions KM practices and performance (Ogunbanwo et al., 2019; Ohiorenoya and Eboreime, 2014; Ojo, 2016). These studies failed to indicate the size or categorisation of the firms upon which samples were based, especially for those studies carried out in the construction industry. Furthermore, the barriers to KM have not been given adequate attention, and there is no known study to the authors that focused on the barriers to KM among construction SMEs that have been embarked upon in the south-south geological zone of Nigeria. Also, certain factors limit the full-scale implementation of effective KM practices, especially in the construction industry of developing countries like Nigeria with over 95\% SME population.

With this knowledge and information, this study assesses the factors inhibiting comprehensive KM practices among construction SMEs in the south-south region of Nigeria. The purpose of this study was achieved by sampling construction-based professionals who are the main knowledge workers of the construction industry. Construction professionals are the brain behind building planning and designs, specification and costing, and other knowledge-dependent activities for bringing a proposed building project into reality. Construction professionals are the key expert employees of construction organisations (Eze et al., 2020), be it large, small or medium organisations. KM would improve their efficiency and operations which would bring about an overall improvement in the level of productivity and competitiveness of construction organisations. The communication and sharing of experiences, knowledge and lessons learnt among employees, have an enhanced impact on performance and productivity (von Krogh, 2002). This study will be useful to SMEs, especially construction organisations in improving the skills, experiences and knowledge of their employees for better performance, productivity and competitive niche. Productivity and performance impact profitability, safety, waste and the environment. The implication is it contributes to the economic, social and environmental dimensions of sustainability for nations.

The south-south region of Nigeria has six states, and there is a possibility of having differing opinions from the target participants of the small and medium organisation and across the study area. It is based on this that the hypothesis $\left(H_{0}\right)$ was formulated.

\section{$H_{0}$ : There is no significant statistical difference in the views of the small and medium construction organisations concerning the inhibiting factors to KM on construction projects.}

\section{Literature Review}

\subsection{Small and Medium Scale Enterprises and Construction SMEs}

SMEs play an important role and serve as the major driver of entrepreneurial skills diffusion, innovation and employment in modern economies (Mishra, 2019). Odeyemi (2003) submit that SMEs are the foundation for driving and sustaining economic growth. In addition, 70\% of industrial employment is provided by SMEs and they also contribute to over $50 \%$ of GDP (Odeyemi, 2003). The SMEs strengthen the economies of nations because they are more in numbers compared to the large organisations.

According to Donyavi and Flanagan (2009), a larger proportion of the contracting and subcontracting organisations in the construction sector are SMEs. In Malaysia, Manu et al. (2018) confirmed that the majority of the micro-business construction organisations are SMEs. In the United Kingdom, SMEs make up $99.9 \%$ of the construction-based organisations, and $99 \%$ of businesses are SMEs in the EU (Lu, 2018; European Commission, 2015). Usman et al. (2014) submitted that construction SMEs account for $17.7 \%$ of Mexican GDP, $19 \%$ for South Africa, $5 \%$ in Nigerian, and $8 \%$ for Ghana. In spite, this huge impact of the SMEs on economic growth and development, they have not exploited the full benefits of 
KM practices (Marra et al., 2012; Durst and Edvardsson, 2012). This has impacted negatively on their productivity, performance and survival. The KM application level of SMEs is limited by certain factors which are inherent in their characteristics and environment of operations.

\subsection{Knowledge and KM Ingredients}

Suhana et al. (2020) posit that knowledge is a vital organisational resource. It is an organisational asset that is often not used by the originator (Rechberg and Syed, 2013). Knowledge is the possession, action or act of knowing or having experience through the participation of actors (employees). According to Nisha (2018), KM is the creation, circulation, exploitation and controlling of information and data of an organisation. Kim et al. (2004) defined KM as a systematic approach in the administration of the valuable resources of an organisation, via the promotion of an integrated technique of identifying, capturing, structuring, organizing, retrieving, sharing, and evaluating knowledge assets. KM permits organisations to improve the productivity of generation, categorisation, and transfer of activities and to leverage their value for both group and individual benefits (Ruggles, 1997). Onyeagam et al. (2020) see KM as a premeditated and planned competitive tool leveraged by construction organisations for surviving the intense competition of the construction sector. It was further reported that $\mathrm{KM}$ improves the organization's competitive niche, reduces risks, improves collaboration, enhances profitability and innovation, reduces problems solving time, enhances pricing of projects, and increases the satisfaction of clients and their patronages. These are the significant benefits of KM implementation in construction organisations (Onyeagam et al., 2020)

The aim of KM is the acquisition, creation, integration and usage of knowledge for the optimum performance of an organization. Historical data, experiences are leveraged for refining the quality and efficiency of the workforce, which in turn impact their productivity. Effective management of organisational knowledge asset results in better organisational output and performance (Suhana et al., 2020). KM involves basically, the management of tacit and explicit knowledge of an organisation for better productivity and performance. Tacit knowledge is a type of knowledge that is difficult to package and share. It exists within or inside of an individual's valuable (Tywoniak, 2007; Collins, 1993). In SMEs, Knowledge is mostly tacit (Indriyani et al., 2020). Knowledge creation begins when tacit knowledge is converted to explicit knowledge. Explicit knowledge exists in data and information forms. This type of knowledge can be shared, exchanged and transferred. They are in a packaged form (Rechberg and Syed, 2014).

KM practices involve the interaction of four major components (i.e., people, process, Content/IT and strategy). According to Onyeagam et al. (2020), the rich knowledge (content) created by the right people (knowledge workers) is stored in an ICT facility for reuse. However, it is through a properly, clearly documented organisational strategy that supports the efforts of the people, process and content/IT. The key ingredients of KM are linked and influence each other to bring about the needed improvement in productivity, performance and progress in an organisation. It is important to stress here that it is the people (organisational managers/leadership) and employees (workers) that propel KM, and a critical success factor for
$\mathrm{KM}$ is the acquisition of the right people. Thus, People are at the nucleus of KM, because they support, sponsor and lead in knowledge sharing. Furthermore, without the people, processes and technology will be meaningless.

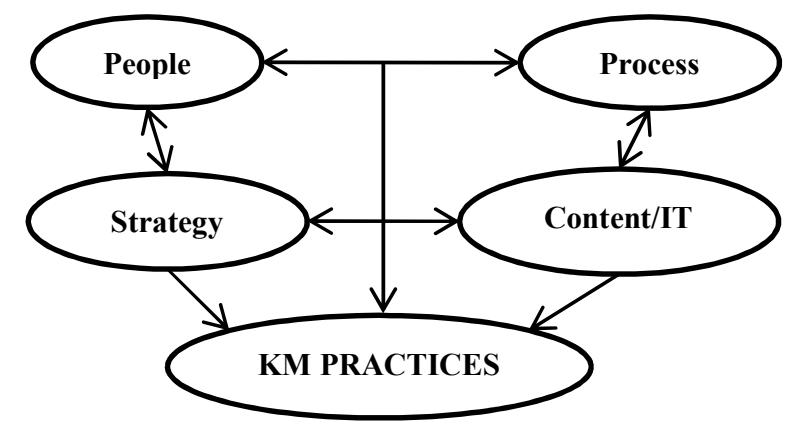

Fig. 1. Interaction of key Ingredient of KM practices

(Modified from Onyeagam et al. (2020))

\subsection{Limiting Factors to KM among Construction Organisations}

$\mathrm{KM}$ is an aspect of the human resource management of an organisation. According to Ugoani (2016), human resource management involves employees who possess specific skills, abilities, knowledge and required work attitudes for undertaking specific responsibility for the overall organisational growth. Companies can locate, catalogue, file, transfer and reused knowledge when a KM system is entrenched in their operations. Ujwary-Gil (2011) posits that employees learn more rapidly, reach vital information quickly, become more efficient easily, and these reflect an obvious enhancement of the effectiveness and efficiency of the entire organisation. Organisations and businesses consider knowledge and its acquisition, production, storage and transfer; as an important aspect of management that create success, competitive advantage and organisational survival. KM processes help in the measurement of organisational knowledge position in the entire value chain of organisations that have taken KM as a focus strategy (Dastyar et al., 2017). According to Donin et al. (2016), knowledge is organisations new strategic imperatives that are critical and form part of organisations functional and operational processes. Its production and distribution have remained an important input towards achieving competitiveness. Balakrishnan and Cheng (2019) assert that in project and production management, different types of knowledge are created. Dastyar et al. (2017) submit that a lot of data are created and do not present any value to managers who are not familiar with their utilisation. Managerial decisions are improved when data are appropriately processed into knowledge and information to support organisational progress and survival strategy.

Generally, KM is the creations, sharing and storage of tacit knowledge. Tacit knowledge may exist at the individual or organisational level. Organisational theories are utilised in decoding tacit knowledge at the level of the organisation, while psychology is used to decode tacit knowledge at the individual level. Tacit knowledge involves soft skills, personal attributes, cooperative partnership development and situational subjective judgments; these are mainly based on intuitive nature and experience gained (Donin et al., 2016). Thus, they are less easily distilled and captured in a more refined structure like explicit knowledge. However, the combination of the unstructured tacit knowledge and the structured explicit 
knowledge helps in the entrenchment of best practices in documentation and other management functions (Donin et al., 2016).

The Full benefits of KM to individuals and/or organisations are limited by certain factors that exist within and /or outside their reach and may come from inefficiencies, traits, trust and culture. The effective management of knowledge at an individual and /or organisational level is dependent on an atmosphere of trust created by organisational culture (Ujwary-Gil, 2011). Enterprise organisational culture influences how dedicated employees will be to KM. A culture of continuous learning and safety from failure.

Inappropriate organisational culture could lead to major barriers to implementation of KM (Ujwary-Gil, 2011), and these barriers are; unwillingness to share knowledge, the mentality of building knowledge for personal competitive advantage, avoiding cooperation with colleagues (hoarding of knowledge), people's mentality, as our nature encourages us to build our competitive, reluctance to delegate authority, language barriers (lack of knowledge of the foreign language) and incompetence to use some information tools. KM implementation barriers are caused by Organisational culture, poor organisational structure, insufficient KM skills by managers and workers, poor management support, improper planning and coordination of design and evaluation, lack of measurable benefits and absence of indicators for performance measurement (Team Collaboration, 2015).

A lot of companies start KM programs in their organisations only to see them fail. The major problems areas preventing the successful implementation of KM are insufficient planning and resources inadequacy, absence of a clear business purpose, lack of accountability and absence of customization (Harvard Business School, 2001). Technology barriers include shortage of hardware, lack of IT literacy, lack of bandwidth. Content barriers include difficulty in transforming tacit knowledge to explicit information and collecting of content for the inventory of knowledge assets, and disregard of knowledge sharing policy by senior managers (Team Collaboration, 2015). Some of the issues of KM highlights by (Garfield, 2017) are funding and support from senior leaders, balancing people, process and technology components, motivations issues, lack of clear vision on how KM should work, the problem of making useful information readily available, among others.

Knowledge sharing is a complex and value-creating activity of organisations (Dale, 2011), and as one of the dimensions of KM, the barriers to its implementation were broadly categorised by (Riege, 2005) into individual barriers, organisational barriers and technological barriers. The main barriers under the individual KM barriers include; dearth of time to share knowledge, the time required to find workers (colleagues) who need specific support and knowledge; fear of loss or reduced job security after sharing; lack of awareness of how valuable knowledge possessed are to other workers; prioritization of explicit knowledge sharing explicit over tacit knowledge such as experiences and know-how requiring learning on the job, surveillance and collaborative problem solving; the use of pull rank-use of strong hierarchy, formal power and position-based status; poor capture, assessment, reaction, communication and lenience with past errors that would improve learning effects on people and organisations; differing levels of experiences; inadequate interaction time and interface between sources and beneficiaries of knowledge, poor interpersonal communication abilities; dissimilarities in age; differences in gender; absence of shared network; variances in the levels of educational; intellectual property ownership for fear of not being recognized by superiors and coworkers; absence of confidence in people for fear of knowledge misuse or taking unmerited credit for it use; lack of trust on the sources of knowledge (with regards to accuracy and credibility); national cultural differences and ethnic background and value and believe system.

The KM barriers related to organisation management as pointed out by Riege (2005) and Dale (2011) are lack of clear integration of KM strategy and sharing initiatives into organisational goals and strategies, unclear communication of benefits and values of KM by company leadership and management, insufficient official and casual space to generate, reflect and share new ideas or knowledge, absence of rewards and acknowledgment systems to motivate knowledge sharing, the existence of a culture that does not support knowledge sharing, insufficient organisational resources for creation and sharing of knowledge, insistence on the top-down flow of knowledge and communication, high level of competition amount units and/or subsidiaries, and poor workplace layout inhibiting knowledge sharing practices. Furthermore, the technology-based barriers are; Impediments to KM resulting from lack of ICT system integration, resistance to use of ICT by employees and managers, lack of knowledge and experience on the application of information technology by managers, and lack of training on technology applications for KM.

It was suggested by Whelton et al. (2002) that organisational culture and associated barriers like fear by employees and their attitudes of resisting the sharing of knowledge need to be proactively confronted. It was also found that other impediments to $\mathrm{KM}$ adoption are; overload of initiative, administrative bureaucracy related to $\mathrm{KM}$, gross inadequacy of infrastructure for information technology, absence of support from top management, problems related to prioritization of $\mathrm{KM}$ and other functions of management, and hitches in clearly communicating KM benefits. According to the study by Korkmaz and Bahidrah (2017), the barriers to KM are the absence of coordination, weak adoption networks of communication, lack of a structural approach by organisations, and cultural issues. Similarly, Oke et al. (2013) found that the top impediments to KM are; funding issues, absence of time for and understanding of KM, absence of qualified technical experts, lack of sufficient and updated data, absence of a successful model of KM in the construction sector, lack of effective communication among construction professionals, among others. In Spain, Feijoo et al. (2015) conducted a questionnaire survey among 580 primary and secondary school teachers. The study was aimed at identifying the barriers to $\mathrm{KM}$ implementation in employee portals and found that the main categories of barriers are flaws associated with innovative design and application, resistance to change, the tough alteration of work practices to a technology atmosphere, ineffective management of change by the administration. Carrillo et al. (2000) found that overload of information, absence of knowledge sharing time, lack of effective application of technology in knowledge sharing 
and challenges of capturing tacit knowledge; are few limiting factors to KM implementation.

Through a theoretical framework and review of industrial cases on KM barriers, BenMoussa (2009) found that the common barriers are; concentration on knowledge supply over knowledge demand, depriving knowledge beneficiaries of the right to determine what knowledge to captured, lack of predetermined practices for the transfer and control of knowledge, and lack of motivation to encourage KM practices among end-users. It has been pointed out that organisational culture is considered one of the greatest factors influencing the success of KM practice on projects, and conceivably the most problematic constraint that must be dealt with by knowledge managers (Davenport et al., 1998; Whelton et al., 2002). Thus, cultural barriers have remained a persistent and vital obstacle that has remained unaddressed in most businesses (Whelton et al., 2002). For Marshall and Sapsed (2000), $\mathrm{KM}$ is a technical and socio-cultural problem that involves the use of IT and the motivation of people to share knowledge for the use and benefit of organisations. In a case study of the construction sector that was focused on identifying the obstacles and drivers of effective KM in the USA, Okere (2017) found that the major three key barriers and enablers to KM are; "awareness of the need and value of knowledge or lack of it, a knowledge-sharing environment or lack of it, and web-enabled and integrated KM systems or lack of it."

Oliva and Kotabe (2019) found that the top 5 barriers to KM in startups in brazil are; lack of resources (staff, time, system) to assess knowledge use, lack of resources for knowledge acquisition, pressure to meet deadlines over a short duration impact on the dissemination of knowledge, resistance to documentation hinders knowledge storage, and commitment only with the current time. A good summary of the impediments to KM was made by Hubert and Lopez (2013). Hubert and Lopez (2013) identified ten high-level common barriers to knowledge sharing in organisations These high-level barriers are relationships, awareness, trust, measures, sponsorship, culture, time, distance, knowledge hoarding, and experience.

In South Africa, Aghimien et al. (2019) found that the key impediment to effective KM in SMEs is related mostly to issues of people, organisational and project demands. The study emphasized human capital development for the proper adoption of $\mathrm{KM}$ practices. The organisation of proper training on $\mathrm{KM}$, and workforce willingness to transfer knowledge possessed. Abrahamson and Goodman-Delahunty (2014) in Canada found that the seven mutually exclusive implementation barriers to KM, and are processes/technology, individual unwillingness, organizational unwillingness, workload/overload, location/structure, leadership, and risk management. Jeswani et al. (2018) identified technology, people and organisation related issues as the most damaging barriers to KM implementation in the IT industry, and suggested incremental efforts in the synchronisation of technology, people and organisation. Kulkarni and Dahiya (2018) in India found that the impediments to the use of KM in SMEs are majorly centred on information and communication technology, human resources, organisation level and market-level issues. Organisations face the challenge of knowing what knowledge to store and /or are unable to define their future knowledge need. Furthermore, lack of motivation, lack of absorptive capacity, and the rapid changes and dynamics in IT tools create time lag to get used to new technology (Kulkarni and Dahiya, 2018). In a study aimed at providing a remedy in establishing the main obstacles that need to be resolved first and to guarantee real KM implementation in the Pakistanis health sector, (Karamat et al., 2018) found that the key barriers that served as the root cause to other barriers are; absence of top management support, Inadequate premeditated planning, absence of backing from the structure of organisations and Non-supporting organisational culture. Thirty-eight factors limiting factors were selected and summarized in Table 1.

\section{Research Methodology}

This study leveraged the electronic questionnaire and snowball sampling to achieve its aim. The study sampled construction professionals working with construction SMEs within the south-south region of Nigeria. The southsouth region has six states (Akwa Ibom State, Bayelsa State, Cross River state, Delta state, Edo state, and Rivers state), and these states are huge revenue generators for the government of Nigeria, as they are rich in oil and gas. The presence of oil in these states makes them a business and investment destination for all categories of companies. Also, the government, both federal and states, are implementing various sizes of construction projects in this region. These attract experts as well as skilled workers to the region. Construction SMEs have spread and larger numerical strength (Eze et al., 2020) and contribute to job creation, drive innovation and healthy competition in the construction market (John et al., 2019). Constructions professionals form the bulk of the professionals engaged by construction-based organisations (Eze et al., 2020). The questionnaire is suitable for studies that cover a wider study area like the south-south region under consideration. It is economical in terms of cost and time and allows for a quantifiable result (Tan, 2011).

The total number of MSMEs in the south-south region of Nigeria is approximately 9800 (1900 for Akwa Ibom state, 300 for Bayelsa state, 1500 for Cross River state, 1500 for Delta state, 2800 for Edo state, and 1800 for Rivers state). These were obtained from the report of Micro, Small, and Medium Enterprises (MSME) National Survey carried out in 2017 and published in 2019 by the National Bureau of Statistics (2019). The study population of 675 $(480+195)$ was arrived at based on the assumption that 5 and 10 professionals will be sampled from the small and medium enterprises, respectively (see Table 2). A similar approach was adopted by (Eze et al., 2020; Adegboyega et al., 2021). From the sample size determination table of (Krejcie \& Morgan, 1970), the nearest population to 675 is 700 , and the equivalent sample size to this sample population is 248 . Thus, the sample size for this study is 248.

The selection of the survey participants was based on certain criteria. These criteria are 1) the professionals must be an employee of construction SMEs, 2) must be well informed about the running of his/her employer, 3) must have an understanding of KM practices, and 4) must have at least five years of work experience within the region and be willing to participate in the study. The snowball sampling technique was adopted for the study as it was difficult to obtain the list of professionals with the set criteria for this current study. 
Table 1. Limiting factors to KM implementation among construction organisations

\begin{tabular}{|c|c|c|}
\hline $\mathbf{S} / \mathbf{N}$ & Factors limiting KM Implementation & Source(s) \\
\hline 1 & Poor interpersonal communication skills & Karamat et al. (2018); Riege (2005); Dale (2011) \\
\hline 2 & $\begin{array}{l}\text { Poor knowledge capture, assessment, reaction, communication and } \\
\text { tolerance }\end{array}$ & Riege (2005); Dale (2011) \\
\hline 3 & Differing levels of experiences & Riege (2005); Dale (2011) \\
\hline 4 & Language barriers (lack of knowledge of the foreign language) & Ujwary-Gil (2011) \\
\hline 5 & Prioritization of sharing explicit over tacit knowledge & Riege (2005); Dale (2011) \\
\hline 6 & Lack of planning and coordination & $\begin{array}{l}\text { Korkmaz and Bahidrah (2017); Team } \\
\text { Collaboration (2015); Karamat et al. (2018) }\end{array}$ \\
\hline 7 & Fear of loss or reduced job security after sharing knowledge & Riege (2005); Dale (2011) \\
\hline 8 & $\begin{array}{l}\text { Lack of awareness of how valuable knowledge possessed are to other } \\
\text { workers }\end{array}$ & Riege (2005); Dale (2011) \\
\hline 9 & Reluctance to delegate authority & Ujwary-Gil (2011) \\
\hline 10 & Problems of prioritisation of KM and other functions of management & Whelton et al. (2002) \\
\hline 11 & $\begin{array}{l}\text { The time required to find workers (colleagues) who need specific } \\
\text { knowledge }\end{array}$ & Riege (2005); Dale (2011) \\
\hline 12 & The uniqueness of construction Projects & $\begin{array}{l}\text { Kazi et al. (1999); Carrillo et al. (2000); Oke et al. } \\
\text { (2013) }\end{array}$ \\
\hline 13 & The problem of Converting knowledge & $\begin{array}{l}\text { Team Collaboration (2015); Kazi et al. (1999); } \\
\text { Carrillo et al. (2000); Oke et al. (2013) }\end{array}$ \\
\hline 14 & Lack of top management support & $\begin{array}{l}\text { Karamat et al. (2018); Garfield (2017); Team } \\
\text { Collaboration (2015); Abrahamson \& Goodman- } \\
\text { Delahunty (2014); Robinson et al. (2005); Oke et } \\
\text { al. (2013); Whelton et al. (2002) }\end{array}$ \\
\hline 15 & Avoiding cooperation with colleagues (hoarding of knowledge) & Ujwary-Gil (2011) \\
\hline 16 & A dearth of time to share knowledge & $\begin{array}{l}\text { Kulkarni and Dahiya (2018); Riege (2005); Dale } \\
\text { (2011); Carrillo et al. (2006); Leal et al. (2017); } \\
\text { Kazi et al. (1999); Oke et al. (2013) }\end{array}$ \\
\hline 17 & $\begin{array}{l}\text { Absence of rewards and recognition systems to motivate knowledge } \\
\text { sharing, }\end{array}$ & Riege (2005); Dale (2011) \\
\hline 18 & $\begin{array}{l}\text { Unclear communication of benefits and values of KM by company } \\
\text { leadership and management, }\end{array}$ & $\begin{array}{l}\text { Riege (2005); Dale (2011); Team Collaboration } \\
\text { (2015); Garfield (2017) }\end{array}$ \\
\hline 19 & $\begin{array}{l}\text { Lack of clear integration of KM strategy and sharing initiatives into } \\
\text { organisation's goals and strategies }\end{array}$ & Riege (2005); Dale (2011) \\
\hline 20 & $\begin{array}{l}\text { The mentality of building knowledge for personal competitive } \\
\text { advantage }\end{array}$ & Ujwary-Gil (2011) \\
\hline 21 & $\begin{array}{l}\text { Lack of knowledge and experience on the application of IT by } \\
\text { managers }\end{array}$ & $\begin{array}{l}\text { Riege (2005); Dale (2011); Team Collaboration } \\
(2015)\end{array}$ \\
\hline 22 & Incompetence to use some information tools. & Ujwary-Gil (2011); Team Collaboration (2015) \\
\hline 23 & $\begin{array}{l}\text { Insufficient formal and informal space to generate, reflect and share } \\
\text { new knowledge, }\end{array}$ & Riege (2005); Dale (2011) \\
\hline 24 & Poor training and intellectual capital & Leal et al. (2017); Aghimien et al. (2019) \\
\hline 25 & The number of SMEs & $\begin{array}{l}\text { Carrillo et al. (2000), Kazi et al. (1999); Oke et al. } \\
(2013)\end{array}$ \\
\hline 26 & Absence of firm structural approach & $\begin{array}{l}\text { Karamat et al. (2018); Korkmaz and Bahidrah } \\
\text { (2017); Kulkarni and Dahiya (2018) }\end{array}$ \\
\hline 27 & Poor communication networks & $\begin{array}{l}\text { Korkmaz and Bahidrah (2017); Kulkarni and } \\
\text { Dahiya (2018) }\end{array}$ \\
\hline 28 & $\begin{array}{l}\text { Insufficient organisational resources for creation and sharing of } \\
\text { knowledge }\end{array}$ & Riege (2005); Dale (2011) \\
\hline 29 & Existence of a culture that does not support knowledge sharing & $\begin{array}{l}\text { Karamat et al. (2018); Riege (2005); Dale (2011); } \\
\text { Team Collaboration (2015) }\end{array}$ \\
\hline 30 & Lack of IT support facilities & $\begin{array}{l}\text { Riege (2005); Abrahamson and Goodman- } \\
\text { Delahunty (2014); Dale (2011); Carrillo et al. } \\
\text { (2000); Kazi et al. (1999); Oke et al. (2013); } \\
\text { Team Collaboration (2015) }\end{array}$ \\
\hline 31 & Poor workplace layout inhibiting knowledge sharing practices. & Riege (2005); Dale (2011) \\
\hline 32 & $\begin{array}{l}\text { Lack of trust in the sources of knowledge (with regards to accuracy and } \\
\text { credibility) }\end{array}$ & Riege (2005); Dale (2011) \\
\hline 33 & Lack of training on technology applications for KM & $\begin{array}{l}\text { Riege (2005); Dale (2011); Karamat et al. (2018); } \\
\text { Jeswani et al. (2018) }\end{array}$ \\
\hline 34 & Unwillingness to share knowledge & $\begin{array}{l}\text { Ujwary-Gil (2011); Abrahamson and Goodman- } \\
\text { Delahunty (2014); Garfield (2017); Aghimien et } \\
\text { al. (2019) }\end{array}$ \\
\hline
\end{tabular}


Table 1. Limiting factors to KM implementation among construction organisations (continued)

\begin{tabular}{lll}
\hline 35 & $\begin{array}{l}\text { Absence of trust in people for fear of knowledge misuse or taking } \\
\text { unmerited credit for its use }\end{array}$ & Riege (2005); Dale (2011) \\
\hline \multirow{3}{*}{36} & Cultural elements & $\begin{array}{l}\text { Karamat et al. (2018); Korkmaz and Bahidrah } \\
\text { (2017); Jeswani et al. (2018); Team Collaboration } \\
\text { (2015); Abrahamson and Goodman-Delahunty } \\
(2014) ; \text { Carrillo et al. (2006); Oke et al. (2013); } \\
\text { Kazi et al. (1999) }\end{array}$ \\
\hline \multirow{2}{*}{37} & $\begin{array}{l}\text { Ownership of intellectual property for fear of not being recognized by } \\
\text { managers and colleagues }\end{array}$ & Riege (2005); Dale (2011) \\
\hline \multirow{2}{*}{38} & Resistance to use of ICT by employees and managers & $\begin{array}{l}\text { Riege (2005); Dale (2011); Abrahamson and } \\
\text { Goodman-Delahunty (2014) }\end{array}$ \\
\hline
\end{tabular}

Contacts were made with the first set of participants after an initial preliminary survey of the SMEs in the study area. These participants then referred the study to others who met the set criteria. The snowball sampling technique has the capability to increase response rate, and it is based on referrals (Atkinson and Flint, 2001; Heckathorn, 2011). The questionnaire was administered electronically, and according to Nwaki and Eze (2020), the electronic means of questionnaire administration is an environmentally friendly means of a survey. The questionnaire has two parts; the first part gathered data on participants' profiles, the second part asked questions on the factors inhibiting the full-scale adoption of KM by construction SMEs. This was based on a 5-point Likert scale, where (5 is the highest scale and 1 is the lowest scale).

One hundred thirty-six complete and useful responses were received and were found adequate for the analysis, and thus represents a $54.84 \%$ response rate. The breakdown of the 136 samples by states showed that; (Akwa Ibom=11 (8.09\%), Bayelsa $=6(4.41 \%)$, Cross River $=25(18.38 \%)$, Delta state $=35(25.0 \%)$, Edo state $=19(13.97 \%)$ and Rivers state $=41(30.15 \%)$. The gathered data were analysed using frequencies, percentages, Mann-Whitney U Test and factor analysis. The participants' profiles were analysed using frequencies and percentages. Data gathered on the factors inhibiting the full-scale KM practices were analysed using factor analysis using principal component analysis (PCA) as the extraction method and varimax rotation as the rotation method. Factor analysis enabled the reduction of the variables into components of manageable proportion. The components grouping is based on the relationships of the cluster of items.

Table 2. Sample population and size

\begin{tabular}{|c|c|c|c|}
\hline & & \multicolumn{2}{|c|}{ Enterprise type } \\
\hline & & Small & Medium \\
\hline & Number of each type & 71288 & 1793 \\
\hline & $\%$ proportion & $0.1716 \%$ & $0.0043 \%$ \\
\hline \multirow{2}{*}{$\begin{array}{l}\text { Construction } \\
\text { businesses }\end{array}$} & $\begin{array}{l}\% \text { Proportion in the } \\
\text { country }\end{array}$ & $1.00 \%$ & $5.00 \%$ \\
\hline & $\begin{array}{l}\text { The number involved } \\
\text { in the construction } \\
\text { business }\end{array}$ & 712.88 & 89.65 \\
\hline \multirow{2}{*}{$\begin{array}{l}\text { Construction } \\
\text { SMEs in } \\
\text { south-south }\end{array}$} & $\begin{array}{l}\text { Approximate } \\
\text { Proportion of SMEs }\end{array}$ & $13.41 \%$ & $13.41 \%$ \\
\hline & $\begin{array}{l}\text { Number of } \\
\text { construction SMEs }\end{array}$ & 96 & 13 \\
\hline \multirow{2}{*}{$\begin{array}{l}\text { Study } \\
\text { population }\end{array}$} & Proposed sample & 5 & 10 \\
\hline & $\begin{array}{l}\text { Total Number of } \\
\text { proposed Sample }\end{array}$ & 480 & 195 \\
\hline
\end{tabular}

The Mann-Whitney U Test enabled the determination of the differences in the opinion of the professionals in small and medium organisations within the study area. It is understood that the participants in the small and mediumsized construction organisation could have a different rating style for the identified barriers. Mann-Whitney U test is suitable for comparing the medians of two participants group (Pallant, 2005). The analyses of this study were performed using a statistical package for social science (IBM, 2011).

The data reliability was carried out using Cronbach's Alpha test, and a reliability index of 0.826 was obtained for the 38 inhibitors to effective KM by SMEs. This shows that the questionnaire is reliable and has high internal consistency. For the normality test, Ghasemi and Zahediasi (2012) suggested the use of the Shapiro-Wilk test when the sample size is small (i.e., < 2000). The data are nonparametric as the $\mathrm{p}$-values obtained for the variables are less than 0.05. This justifies the use of the Mann-Whitney $\mathrm{U}$ test. The methodological flow is summed up in a 6-step chart (Fig. 2).

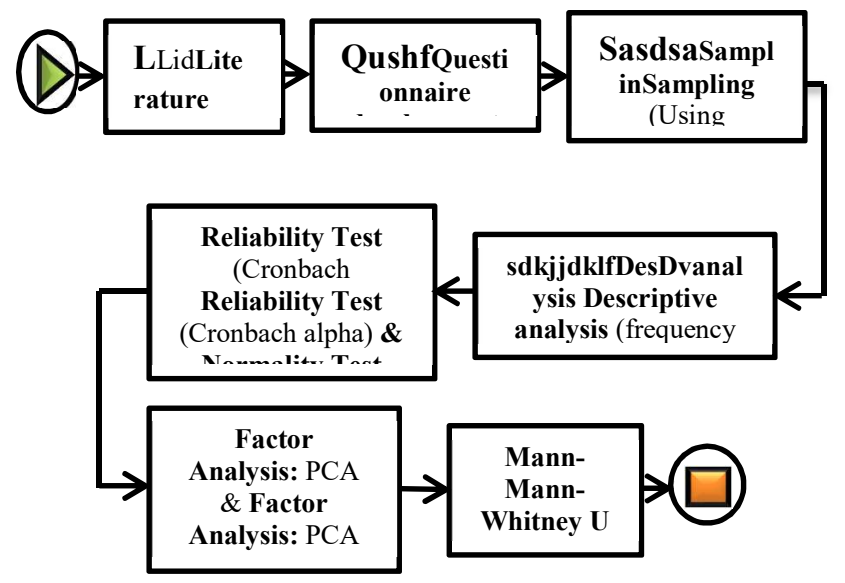

Fig. 2. Methodological flow-chart

\section{Results and Discussion}

\subsection{Participants background information}

Table 3 contains the results of the analysis of the sampled participants' background information. The table reveals that within the study area, 66.91 per cent of the participants work with small organisations and 33.09 per cent work with medium-sized construction organisations. Also, Engineers are more with 36.03 per cent, followed by Quantity Surveyors (26.47 per cent), then Architects (25.74 per cent) and lastly the Builders (11.76 per cent). This shows a fair representation of the major construction professionals employees of construction organisations. The average working experience of the sampled 
participants is 12.97 years. A breakdown of the work experiences shows that; 33.82 per cent have spent about 5 $10 y e a r s$ in the construction industry, 37.50 per cent have 11-15 years of experience, 15.44 per cent have 16-20years of experience, and 13.24 per cent have spent between 21 and above. These indicate that they have gained reasonable and useful experiences that could aid in meeting the study purpose.

Also, the highest academic qualification shows that those with B.Sc./B.Tech is more with (40.44 per cent), this is followed by those with HND and MSc./M.Tech with same (22.79 per cent) each, and then PGD (13.97 per cent) and none of them had a Ph.D. This shows that the participants have the requisite level of educated and credentials to give informed information that will aid this study. Furthermore, the professional membership affiliation of the respondents, shows that the majority ( 86.76 per cent) of them are corporate members of their various professional bodies, only are a fraction of about 13.24 per cent are probationers.

\subsection{Barriers to KM practices in SMEs}

Before carrying out the actual factor analysis, sample suitability, factorability, and adequacy evaluation were done. This started by looking at the sample size and number of variables. Based on the suggestion of Pallant (2005) and Hair et al. (2010), the 136 samples sizes are adequate for factor analysis. There is, however, no agreement on the number of variables for FA. Thus, the 38 variables are deemed adequate for FA. The next stage is to look at the commonalities, Kaiser-Meyer-Olkin (KMO) measure of sampling adequacy, and Bartlett's test of sphericity was further assessed. According to Zhao (2008), in FA, the sample size is less important where the commonalities are at least 0.60 . Communalities values of greater than 0.50 mean that variables fit well in the construct with other variables (Eze et al., 2018). The maximum and minimum communalities are 0.951 and 0.561 , respectively, with an average of 0.638 for the tested variables. The results obtained for the KMO and Bartlett's test in Table 4, meet the submissions by Field (2009), Hair et al., (2010), and Tabachnick and Fidell (2007). Thus, the gathered data are suitable and factorable.

\section{Factors Extraction and Principal component analysis (PCA)}

Having confirmed variables factorability, factor analysis executed utilising principal component analysis (PCA) with varimax rotation as the extraction method. The analysis resulted in five factors extracted that account for about $53.59 \%$ of the total cumulative variance explained. The extracted factors have eigenvalues greater than 1 . This $53.59 \%$ obtained for the final PCA and varimax rotation statistics met the suggestions of Pallant (2007) and Stern (2010) regarding factors extraction expected to be higher than $50 \%$. The retained factors in Table 5 have factor loading of more than 0.50 , and this is inconsonant with the suggestion of Spector (1992). Furthermore, the highest factor loading among the variables that are loaded under a component is given priority in naming cluster that is difficult in obtaining a suitable name for.

Table 3. Respondents and organisation profile

\begin{tabular}{|c|c|c|c|}
\hline Variables & Classification & Freq. & Per cent \\
\hline \multirow[t]{3}{*}{ Organisational size } & Small organisation & 91 & 66.91 \\
\hline & Medium organisation & 45 & 33.09 \\
\hline & TOTAL & 136 & 100.00 \\
\hline \multirow[t]{5}{*}{ Participants professions } & Architect & 35 & 25.74 \\
\hline & Builders & 16 & 11.76 \\
\hline & Engineers (Civil/structural \& Services) & 49 & 36.03 \\
\hline & Quantity Surveyors & 36 & 26.47 \\
\hline & TOTAL & 136 & 100.00 \\
\hline \multirow[t]{5}{*}{ Years of experience } & $5-10$ years & 46 & 33.82 \\
\hline & $11-15$ years & 51 & 37.50 \\
\hline & $16-20$ years & 21 & 15.44 \\
\hline & 21-above & 18 & 13.24 \\
\hline & TOTAL & 136 & 100.00 \\
\hline \multirow[t]{6}{*}{ Highest Educational Qualification } & Higher National Diploma (HND) & 31 & 22.79 \\
\hline & Postgraduate Diploma (PGD) & 19 & 13.97 \\
\hline & Bachelor of Science/technology (B.Sc./B.Tech) & 55 & 40.44 \\
\hline & Master’s Degree (MSc./M.Tech.) & 31 & 22.79 \\
\hline & Doctorate $(\mathrm{PhD})$ & 0 & 0.00 \\
\hline & TOTAL & 136 & 100.00 \\
\hline \multirow[t]{6}{*}{ Participants Professional Affiliation } & Member Nigerian Institute of Architect (MNIA) & 31 & 22.79 \\
\hline & Member Nigerian Institute of Builders (MNIOB) & 12 & 8.82 \\
\hline & Member Nigerian Society of Engineers (MNSE) & 44 & 32.35 \\
\hline & Member Nigerian Institute of Quantity Surveyors (MNIQS) & 31 & 22.79 \\
\hline & Probationer & 18 & 13.24 \\
\hline & TOTAL & 136 & 100.00 \\
\hline
\end{tabular}


Table 4. KMO and Bartlett's Test

\begin{tabular}{llc}
\hline Kaiser-Meyer-Olkin Measure of & 0.687 \\
$\begin{array}{l}\text { Sampling Adequacy. } \\
\text { Bartlett's Test of }\end{array}$ & Approx. Chi- & 3085.350 \\
Sphericity & Square & 703 \\
& Df & 0.0000 \\
\hline
\end{tabular}

From Table 5, the first component has nine variables loaded under it, and they account for $18.97 \%$ of the total variance and 7.21 Eigenvalues of the extracted items. The items loaded under this component are; lack of IT support facilities, lack of knowledge and experience on the application of IT by managers, lack of training on technology applications for KM, a large number of SMEs, the existence of a culture that does not support knowledge sharing, Poor communication networks, lack of clear integration of KM strategy and sharing initiatives into organisations goals and strategies, Absence of firms structural approach, insufficient formal and informal space to generate, reflect and share new knowledge. A critical examination of the latent characteristics of these variables led to naming it 'Technology related barriers'. Technology plays a critical role in knowledge capturing, storage and retrieval for organisations. Information technology is one of the components needed to make the creation of the content easy and improve accessibility and reuse (Onyeagam et al., 2020). Construction SMEs are lagging in the adoption of technologies in their operations. Technology is a barrier to effective KM practices as reported by Feijoo et al. (2015). It was reported that the tough alteration of work practices to a technology environment is among the barriers to $\mathrm{KM}$ implementation among employees. Carrillo et al. (2000) found that lack of effective application of technology for knowledge sharing and the challenge of capturing tacit knowledge are the drawbacks to KM implementation.

Table 5. Rotated component matrix of KM barriers

\begin{tabular}{|c|c|c|c|c|c|}
\hline \multirow{2}{*}{ Variables } & \multicolumn{5}{|c|}{ Component } \\
\hline & 1 & 2 & 3 & 4 & 5 \\
\hline Lack of IT support facilities & 0.769 & & & & \\
\hline $\begin{array}{l}\text { Lack of knowledge and experience on the application of IT by } \\
\text { managers }\end{array}$ & 0.769 & & & & \\
\hline Lack of training on technology applications for KM & 0.680 & & & & \\
\hline The large number of SMEs & 0.635 & & & & \\
\hline Existence of a culture that does not support knowledge sharing, & 0.624 & & & & \\
\hline Poor communication networks & 0.616 & & & & \\
\hline $\begin{array}{l}\text { Lack of clear integration of KM strategy and sharing initiatives into } \\
\text { organisations goals and strategies }\end{array}$ & 0.605 & & & & \\
\hline Absence of firms structural approach & 0.597 & & & & \\
\hline $\begin{array}{l}\text { Insufficient formal and informal space to generate, reflect and share } \\
\text { new knowledge }\end{array}$ & 0.533 & & & & \\
\hline Cultural elements & & 0.825 & & & \\
\hline Resistance to the use of ICT by employees and managers & & 0.821 & & & \\
\hline Low level of training/intellectual capital & & 0.788 & & & \\
\hline Poor capture, assessment, reaction, communication and tolerance & & 0.660 & & & \\
\hline Differing levels of experiences & & 0.619 & & & \\
\hline $\begin{array}{l}\text { Absence of rewards and recognition systems to motivate knowledge } \\
\text { sharing, }\end{array}$ & & & 0.795 & & \\
\hline A dearth of time to share knowledge & & & 0.762 & & \\
\hline $\begin{array}{l}\text { Absence of trust in the sources of knowledge (with regards to } \\
\text { accuracy and credibility) }\end{array}$ & & & 0.751 & & \\
\hline Problems of prioritisation of $\mathrm{KM}$ and other functions of management & & & 0.740 & & \\
\hline Poor workplace layout inhibiting knowledge sharing practices. & & & 0.696 & & \\
\hline $\begin{array}{l}\text { Lack of awareness of how valuable knowledge possessed are to other } \\
\text { workers }\end{array}$ & & & & 0.612 & \\
\hline $\begin{array}{l}\text { Unclear communication of benefits and values of KM by company } \\
\text { leadership and management }\end{array}$ & & & & 0.582 & \\
\hline Language barriers (lack of knowledge of the foreign language) & & & & 0.533 & \\
\hline The problem of Converting Knowledge & & & & 0.524 & \\
\hline Avoiding cooperation with colleagues (hoarding of knowledge) & & & & 0.508 & \\
\hline Fear of loss or reduced job security after sharing knowledge & & & & & 0.782 \\
\hline Unwillingness to share knowledge & & & & & 0.698 \\
\hline Poor interpersonal communication skills & & & & & 0.693 \\
\hline Lack of coordination & & & & & 0.606 \\
\hline Eigenvalues & 7.21 & 4.31 & 3.21 & 2.03 & 1.59 \\
\hline$\%$ of Variance & 18.97 & 11.34 & 9.50 & 8.45 & 5.33 \\
\hline Cumulative \% & 18.97 & 30.31 & 39.80 & 48.25 & 53.59 \\
\hline Number of variables & 9 & 5 & 5 & 5 & 4 \\
\hline Total factor loading & 5.828 & 3.714 & 3.744 & 2.758 & 2.779 \\
\hline
\end{tabular}


This study is also in support of the studies of (Riege, 2005; Dale, 2011). It was found that the key technologybased barriers are lack of ICT system integration, resistance to use of ICT by employees and managers, lack of knowledge and experience on the application of information technology by managers, and lack of training on technology applications for KM.

The second component contains five items and accounts for $11.34 \%$ of the total variance explained. This component is named 'cultural and management barriers' after a cursory examination of the latent features of the items loaded unto it. The items that loaded onto this component are cultural elements, resistance to use of ICT by employees and managers, Low level of training/intellectual capital, poor capture, assessment, reaction, communication and tolerance, and differing levels of experiences. Culture and management are inseparable in the affairs of any organisations. Entrenching the culture of $\mathrm{KM}$ in an organisation is a key to the successful implementation of $\mathrm{KM}$ and management supports is critical for the sustenance of the KM culture of an organisation. Ujwary-Gil (2011) posits that the effective management of knowledge at an individual and /or organisational level is dependent on an atmosphere of trust created by organisational culture. Enterprise organizational culture influences how dedicated employees will respond to KM. Whelton et al. (2002) found that organisational culture and lack of top management support are among the impediments to KM adoption. Similarly, Korkmaz and Bahidrah (2017) lack of firms' structural approach and culture are barriers to KM. Culture and management support helps to bring the needed trust and motivation to share knowledge. Among the major barriers and enablers of KM found by Okere (2017) is the environment to share knowledge or a lack of it. Thus, culture and management create this environment.

The 3rd component has five items that accounted for $9.50 \%$ of the total variance explained. The items loading under these components are the absence of rewards and recognition systems to motivate knowledge sharing, a dearth of time to share knowledge, absence of trust in the sources of knowledge (with regards to accuracy and credibility), problems of prioritisation of $\mathrm{KM}$ and other functions of management, poor workplace layout inhibiting knowledge sharing practices. This component was named 'Motivation and Time barriers'. The sharing of tacit knowledge is anchored on an effective motivation of the employee and available adequate time to share the knowledge. Oliva and Kotabe (2019) found that the top 5 barriers to KM in startups in Brazil are lack of resources (staff, time, system) to assess knowledge use, lack of resources for knowledge acquisition. One of the top 5 barriers found by Oliva and Kotabe (2019) is pressure for results in a short period affect knowledge dissemination. Oke et al. (2013) also found that lack of time and understanding of KM are among the top impediments to KM. The absence of rewards and recognition systems to motivate knowledge sharing was among the organisational management barriers to KM reported by Riege (2005).

Awareness and communication barriers' is the name of the 4th component, and this component has five items accounting for about $8.45 \%$ of the total variance explained. These items are; lack of awareness of how valuable knowledge possessed are to other workers, unclear communication of benefits and values of KM by company leadership and management, Language barriers (lack of knowledge of the foreign language), the problem of Converting knowledge, and avoiding cooperation with colleagues (hoarding of knowledge). Awareness is the key to understanding the values and benefits of KM. Understanding the benefits of KM requires an effective communication system within the organisation and among employees. One of the three key barriers and enablers to KM reported by Okere (2017) is an awareness of the need and value of knowledge or lack of it. Poor interpersonal communication skills and unclear communication of benefits and values of KM by company leadership and management were found by Riege (2005) and Dale (2011) to be among the barriers to KM. Korkmaz and Bahidrah (2017) reported that the weak utilisation of the communication network is a barrier to KM. Oke et al. (2013) also found that the lack of effective communication among construction professionals are barriers to $\mathrm{KM}$ among

Four factors loaded under the 5 th component and account for $5.33 \%$ of the total variance explained. The four items are fear of loss or reduced job security after sharing knowledge, unwillingness to share knowledge, poor interpersonal communication skills, and lack of coordination. Following the examination of these variables, the cluster was named 'Insecurity barriers'. The insecurity barriers are closely linked to individual perception regarding what becomes of his/her employment after sharing tacit knowledge. It is a general perception that when what makes an employee valued is shared by the said employee, there is a tendency that he/she will no longer be needed. The fear of job loss after sharing knowledge was identified by Riege (2005) as the individual barrier to KM. Unwillingness to share knowledge and fear of job loss are barriers resulting from poor or weak organisational culture and management support. According to Ujwary-Gil (2011), inappropriate organisational culture leads to major barriers to $\mathrm{KM}$ implementation, and one of such barriers is an unwillingness to share knowledge. The construction SMEs uses a lot of causal labour, which even worsens and impedes knowledge sharing among the workforce.

Fig. 3 shows the total factor loading for major components. It can be seen that the technology-related barrier is the most critical barriers that need to be overcome by the SMEs for effective KM practices to be entrenched. Motivation and time barrier are the second most critical barriers to KM, and then cultural and management barriers. Insecurity barriers and awareness and communication barriers must also be overcome by the SMEs ownermanagers and other top management for effective KM practices to be entrenched. Overcoming these major barriers is necessary for SMEs to enjoy the full potentials of effective KM practices.

Table 6 shows the Mann-Whitney U test result of the participants from small and medium organisations. The construction professional in the small and medium-sized organisation have a unified view of the barriers identified from the literature. There is no statistically significant difference in the views of the participants from small and medium organisations within the different states of the study area. This is based on the significant p-value $(0.081)$ obtained, which is greater than 0.05 . 


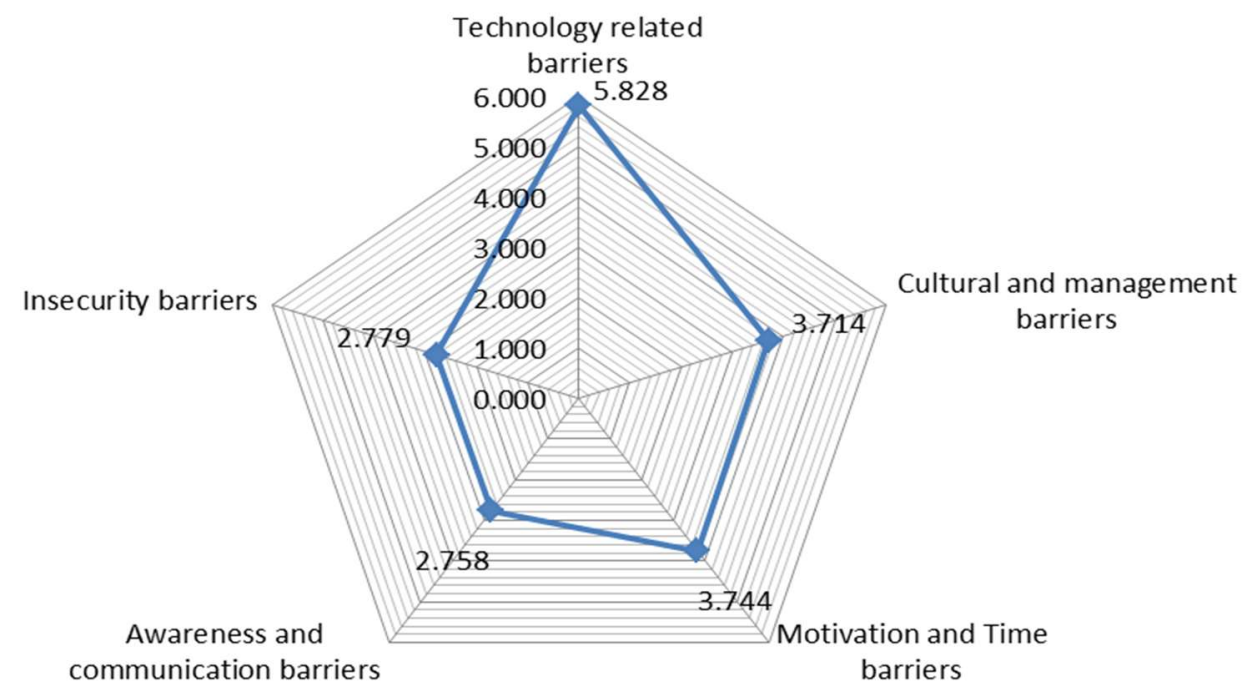

Fig. 3. Total factor loading for components

Table 6. Mann-Whitney U test

\begin{tabular}{lccccccc}
\hline Sampled organisations & $\mathbf{N}$ & $\begin{array}{c}\text { Mean } \\
\text { rank }\end{array}$ & $\begin{array}{c}\text { Sum of } \\
\text { ranks }\end{array}$ & $\begin{array}{c}\text { Mann- } \\
\text { Whitney U }\end{array}$ & $\begin{array}{c}\text { Wilcoxon } \\
\text { W }\end{array}$ & $\begin{array}{c}\text { Z } \\
\text { Asymp. Sig. (2- } \\
\text { tailed) }\end{array}$ \\
\hline $\begin{array}{l}\text { Small organisation } \\
\text { Medium organisations } \\
\quad\end{array}$ & 91 & 74.510 & 6780.410 & 1500.5 & 2535.5 & -1.531 & 0.081 \\
$\quad$ Total & $\mathbf{1 3 6}$ & & & & & \\
\hline
\end{tabular}

\section{Conclusion and Recommendations}

The objective of this study was to determine the factors limiting comprehensive KM practices among construction SMEs in the south-south region of Nigeria. The wellstructured electronic questionnaire administered to construction professional employees of SMEs was used to gather data, and snowball sampling techniques were used in selecting the participants. Factor analysis and MannWhitney U test were used to analysed the gathered data, and critical findings were made.

It was found that the major cluster of factors limiting comprehensive KM practices implementation by SMEs is technology-related barriers, cultural and management barriers, motivation and time barriers, awareness and communication barriers, and insecurity barriers. Also, there is no statistical significance in the views of the limiting factors by participants from the small and medium-sized organisations within the study area. KM is critical to improving the productivity, survival and overall performance of construction organisations. These barriers are although inherent in the structure, organisation and operations of the SMEs can still be overcome. Construction project delivery involves working together with skilled and knowledgeable workers to achieve the project objectives. The activities of construction projects are carried out by humans (workers), and KM is a tactical and strategic management tool for improving their quality and efficiency for faster, better and sustainable performance and productivity. The productivity of the workers will translate to the productivity of the organisation and it will improve the organisation's profitability, competitiveness and customer base.

Based on how strategic KM is to organisational productivity, growth and survival. It is recommended that adequate support is needed from the government to ensure that the needed finances for the provision of training, and boosting investment technology for creating, capturing, and storage and use of knowledge are provided. Government support and adequate funding of the organisation are needed to overcome technology barriers to KM. An organisational culture that will provide the needed environment that encourages knowledge sharing is required to be created by the management. The top management of the SMEs should support the creation, acquisition, sharing, retention and application of organisational knowledge assets for effective productivity and competitiveness. Management support is therefore critical for overcoming the major barriers identified in this study.

This study's outcome is fundamental to the construction industry dominated by SMEs with limited application and appreciation of KM. The management of the SMEs is informed about the key barriers to KM implementation. This will enable them to prepare and map out strategies for overcoming them to improve their productivity and performance. This study also adds to the few existing bodies of knowledge on KM barriers among SMEs. This study is limited by geographical boundary, sample size and participants. Based on this, a similar study should be conducted in other regions of the country or other countries of Africa. This will make results available for comparison. Furthermore, a study that will investigate the relationship between organisational and individual-based barriers to $\mathrm{KM}$ and construction project delivery should be embarked upon. KM improves productivity, competition and enhances the survival of organisations. A study that will look at how KM practices can be used to improve construction health and safety performance in the construction industry could be carried out. 


\section{References}

Abrahamson, D. E. and Goodman-Delahunty, J. (2014). Impediments to information and knowledge sharing within policing. SAGE Open, 4(1), 215824401351936.

Adegboyega, A. A., Eze, C. E., and Sofolahan, O. (2021). Health and safety (HS) risks normalization in the construction industry: The SMEs perspective. Independent Journal of Management \& Production, 12(5) (Pre-print version) 1466-1495.

Ademeso, O. S. and Windapo, A. O. (2008). Relationship between material management approach and scheduled project completion time. COBRA 2008 - Construction and Building Research Conference of the Royal Institution of Chartered Surveyors.

Aghimien, D., Aigbavboa, C., Gomes, F., and Thwala, W. (2019). Barriers to knowledge management in small and medium construction companies in South Africa. In: Skibniewski, M. J. and Miklos Hajdu, M.(Ed.). Proceedings of Creative Construction Conference 2019, CCC 2019, June 29 - July 2 2019, Budapest, Hungary, p. 213-219.

Alhaji, K. M., Amiruddin, R., and Abdullah, F. (2013a). Knowledge sharing practices in construction organisation in Nigeria. International Journal of Engineering Research \& Technology, 2(1), 1-10.

Alhaji, K. M., Amiruddin, R., and Abdullah, F. (2013b). Project knowledge management in civil engineering construction firms in Nigeria. Australian Journal of Basic and Applied Sciences, 7(2), 54-62.

Atkinson, R. and Flint, J. (2001). Accessing hidden and hard-to-reach populations: snowball research strategies. Social Research Update, 33(1), 1-4.

Balakrishnan, J. and Cheng, C. H. (2019). The role of the knowledge intermediary in evangelical project and production management theories. Journal of Engineering, Project, and Production Management, 9 (1), 48-55.

BenMoussa, C. (2009). Barriers to knowledge management: A theoretical framework and a review of industrial cases. World Academy of Science, Engineering and Technology, 30, 901-911.

Brown, B., Chartrand, M., Lambert, M., Nicholas, J., and Wolfe, M. (2003). Knowledge sharing: methods, meetings and tools. knowledge management secretariat. Canadian International Development Agency (CIDA). Canada.

Carrillo, P. M., Anumba, C. J., and Kamara, J. M. (2000). Knowledge management strategy for construction: Key IT and contextual issues. Construction Informatics Digital Library, 28-30.

Centobelli, P., Cerchione, R., and Esposito, E. (2019). Efficiency and effectiveness of knowledge management systems in SMEs. Production Planning \& Control, 30(9), 779-791.

Chen, L. and Fong, P. S. W. (2015). Evaluation of knowledge management performance: An organic approach. Information and Management, 52(4), 431453.

Collins, H. (1993). The structure of knowledge. Social Research, 60(1), 95-116.

Dale, S. (2011). 36 Knowledge sharing barriers. Retrieved from http://www.stephendale.com/2011/10/26/36knowledge-sharing-barriers/

Dastyar, B., Kazemnejad, H., Sereshgi, A. A., and Jabalameli, M. A. (2017). Using data mining techniques to develop knowledge management in organizations: A review. Journal of Engineering, Project, and Production Management, 7(2), 80-89.

Davenport, T. H., De Long, D. W., and Beers, M. C., (1998). Successful knowledge management projects, sloan management review, Winter, 43-57. Abi/Inform Global.

Donin, C., Rizzatti, E., Geiger, K., and Sartori, T. (2016). Applied knowledge management in small design firms: Case study. Independent Journal Of Management \& Production, 7(3), 989-1004.

Donyavi, S. and Flanagan, R. (2009). The impact of effective material management on construction site performance for small and medium sized construction enterprises. In $A$. R. J. Dainty (Ed.), Proceedings of the 25th Annual ARCOM Conference (pp. 11-20). Nottingham: Association of Researchers in Construction Management.

Durst, S. and Edvardsson, I. R. (2012). Knowledge management in SMEs: A literature review. Journal of Knowledge Management, 16, 879-903.

European Commission. (2015). User guide to the SME definition. Publications Office of the European Union. Luxembourg.

Eze, C. E., Awodele, I. A., Adegboyega, A. A., Onyeagam, O. P., and Guto, J. A. (2020). Assessment of the triggers of inefficient materials management practices by construction SMEs in Nigeria. International Journal of Real Estate Studies,14(1), 38-56.

Eze, E. C, Idiake, J. E., and Ganiyu, B. O. (2018). Analysis of rework risk triggers in the Nigerian construction industry. Organization, Technology and Management in Construction, 10(1), 1778-1793.

Feijoo, H. M. P., Ordaz, M. G., and López, F. J. M. (2015). Barriers for the implementation of knowledge management in employee portals. Procedia Computer Science, 64, $506-513$.

Field, A. (2009). Discovering statistics using SPSS: introducing statistical method. 3rd ed. Sage Publications. Thousand Oaks, CA.

Garfield, S. (2017). 15 Issues in Knowledge Management. Retrieved from https://stangarfield.medium.com/15issues-in-knowledge-management-1190e2d4537e

Ghasemi, A. and Zahediasl, S. (2012). Normality test for statistical analysis: a guide for non-statisticians. International Journal of Endocrinology and Metabolism, 10(2), 486-489.

Gilson, L. L. and Shalley, C. E. (2004). A little creativity goes a long way: an examination of terms' engagement in creative processes. Journal of Management, 30(4), 453-470.

Hair, J. F., Black, W. C., Babin, B. J., and Anderson, R. E. (2010). Multivariate data analysis (7th Ed.). Pearson. New York.

Harvard Business School. (2001). Knowledge Management: Four Obstacles to Overcome. Retrieved form https://hbswk.hbs.edu/archive/knowledgemanagement-four-obstacles-to-overcome

Heckathorn, D. D. (2011). Comments: snowballing versus respondent-driven sampling. Sociological Methodology, 41(1), 355-366.

Hubert, C. and Lopez, B. (2013). Breaking the barriers to knowledge sharing. American Productivity and Quality Center, (K04558), 1-6.

IBM. (2011). IBM SPSS Statistics for Windows, Version 20.0. IBM Corp. Armonk, NY.

Idris, K. M. and Kolawole, A. R. (2016). Influence of knowledge management critical success factors on 
organizational performance in Nigeria construction industry. Ethiopian Journal of Environmental Studies and Management, 9(3), 315-325.

Indriyani, R., Eliyana, A., Sobirin, A., and Nathanael, S. (2020). The effect of knowledge sharing and supply chain management on opportunity recognition through management skill in the food industry of SMEs. International Journal of Supply Chain Management, 9(3), 598-604.

Jeswani, S., Kharabe, R., and Jeswani, S. (2018). Understanding barriers of knowledge management implementation (interpretive structural modelling approach). International Journal of Management, IT and Engineering, 8(12), 30-53.

John, T. A., Shakantu, W. W. M., and Olaku, A. P. (2019). Dominant innovations of successful construction micro, small, and medium enterprises (CMSMEs) in Northern Nigeria. In S. Laryea and E. Essah (Eds.), Proceedings of the West Africa Built Environment Research (WABER) Conference (pp. 467-477). Accra: West Africa Built Environment Research (WABER) Conference.

Karamat, J. Shurong, T., Ahmad, N., Waheed, A., and Khan, S. (2018). Barriers to knowledge management in the health sector of Pakistan. Sustainability, 10, 1-22.

Korkmaz, K. A., and Bahidrah, S. (2017). Implementation of Knowledge Management in Construction Projects. Advancements in Civil Engineering \& Technology, 2(3), 1-14.

Kim, K., Lim, S., and Mitchell, B. (2004). Building a knowledge model: A decision-making approach. Journal of Knowledge Management Practice, 5(4), 300-310.

Koochakzadeh, R. S. and Behzadi, S. (2019). The role of KM tactical factors in supply chain management for gaining competitive advantage. International Journal of Supply Chain Management, 8(2), 836-851.

Krejcie, R. V. and Morgan, D. W. (1970). Determining sample size for research activities. Educational and Psychological Measurement, 30, 607-610.

Kulkarni, R. and Dahiya, R. (2018). Implementation barriers for knowledge management for SMEs in Indian construction industry. Published Degree project, Estate and Construction Management Master of Science, Royal Institute of Technology, Sweden.

$\mathrm{Lu}, \mathrm{L}$. (2018). Promoting SME finance in the context of the fintech revolution: A case study of the UK's practice and regulation. Banking and Finance Law Review, 33(3), 317-343.

Manu, P., Mahamadu, A. M., Phung, V. M., Nguyen, T. T., Ath, C., Heng, A. Y. T., and Kit, S. C. (2018). Health and safety management practices of contractors in South East Asia: A multi country study of Cambodia, Vietnam and Malaysia. Safety Science, (107), 188-201.

Marra, M., Ho, W., and Edwards, J. S. (2012). Supply chain knowledge management: A literature review. Experts System Application, 39, 6103-6110.

Marshall, N. and Sapsed, J. (2000). The limits of Disembodied Knowledge: Challenges of inter-project learning in the production of complex products and systems. In Knowledge management: Concepts and Controversies.

Mishra, N. (2019). Knowledge management practice for effective operations in SMEs. Production Planning \& Control, 30(10-12), 795-798.
National Bureau of Statistics. (2019). Micro, small and medium enterprises (MSEM) national survey 2017 report. NBS. Abuja.

Nisha, R. (2018). Knowledge management and recovery processes using IT: An approach towards data mining. International Journal of Supply Chain Management, $7(6), 57-60$

Nwaki, W. N. and Eze, C. E. (2020). Construction as a panacea for poor construction projects performance. ITEGAM-Journal of Engineering and Technology for Industrial Applications (JETIA), 6(26), 61-72.

Odeyemi, W. O. (2003). Empirical analysis of agricultural growth and unemployment in Nigeria. African Journal of Agricultural Research, 3(7), 465-468.

Ogunbanwo, A. S., Okesola, J. O., and Buckley, S. (2019). Knowledge management awareness assessment in Nigerian tertiary institutions. F1000Research, 8:608.

Ohiorenoya, J. O. and Eboreime, O. F. (2014). Knowledge management practices and performance in Nigerian universities. European Scientific Journal, 10(16), 400416.

Ojo, A. (2016). Knowledge management in Nigerian universities: A conceptual model. Interdisciplinary Journal of Information, Knowledge, and Management, 11(2), 331-345.

Oke, A. E., Ogunsemi, D. R., and Adeeko, O. C. (2013). Assessment of knowledge management among construction professionals in Nigeria. Journal of Construction Project Management and Innovation, 3(2), 660-679.

Okere, G. O. (2017). Barriers and enablers of effective knowledge management: a case in the construction sector. The Electronic Journal of Knowledge Management, 15(2), 85-97.

Oliva, F. L. and Kotabe, M. (2019). Barriers, practices, methods and knowledge management tools in startups. Journal of Knowledge Management, 23(9), 1838-1856.

Onyeagam, O., Nwaki, W., Obonadhuze, B., and Zakariyau, M. (2020). The Impact Of Knowledge Management Practices On The Survival And Sustenance Of Construction Organisations. CSID Journal of Infrastructure Development, 3(2), 173-188.

Pallant, J. (2007). SPSS Survival Manual: A Step-By-Step Guide to Data Analysis Using SPSS version 15, 3rd edition. Open University Press. England.

Rechberg, I. and Syed, J. (2013). Ethical issues in knowledge management: Conflict of knowledge ownership. Journal of Knowledge Management, 17(6), 828-847.

Rechberg, I., and Syed, J. (2014). Knowledge management practices and the focus on the individual. International Journal of Knowledge Management, 10(1), 26-42.

Riege, A. (2005). Three-dozen knowledge-sharing barriers managers must consider. Journal of Knowledge Management, 9(3), 18-35.

Robinson, H. S., Carrillo, P. M., Anumba, C. J., and AlGhassani, A. M. (2005). Knowledge management practice in large construction organization. Engineering, Construction and Architectural Management, 12(2), 431-444.

Roner, E. (2019). How to Boost Productivity with Knowledge Management Systems. Retrieved from https://blog.prialto.com/how-to-boost-productivitywith-knowledge-management-systems.

Ruggles, R. (1997). Knowledge management tools. Butterworth-Heinemann. Boston. 
Santoso, A. (2020). Knowledge management, supply chain marketing implementation and marketing capabilities and tourism industry performance in Indonesia. International Journal of Supply Chain Management, 9(3), 1003-1012.

Siemieniuch, C. E. and Sinclair, M. A. (1999). Organisational aspects of knowledge life-cycle management in manufacturing. International Journal of Human-Computer Studies, 51(3), 517-547.

Spector, P. (1992). Summated rating scale construction: An introduction. Sage Publications. Newbaury Park, California.

Stern, L. (2010). A visual approach to SPSS for Windows: a guide to SPSS 17.0. 2nd ed. Allyn and Bacon. Boston.

Suhana, S., Suharnomo, S., Mas'ud, F., Mansyur, A., Febrianto, B., and Santoso, I. H. (2020). Investigating the role of the knowledge sharing and innovative behavior in supply chain management. International Journal of Supply Chain Management, 9(3),871-880.

Suraj, O. A. and Ajiferuke, I. (2013). Knowledge management practices in the Nigerian telecommunications industry. Knowledge and Process Management, 20(1), 30-39.

Tabachnick, B. G. and Fidell, L. S. (2007). Using multivariate statistics (5th ed.). Pearson Education Inc. Boston, MA.

Tan, W. C. K. (2011). Practical research methods. Pearson Custom, ISBN: -13: 978-9810680213. Singapore.

Team Collaboration. (2015). What are the Common Barriers to Knowledge Management in Organizations? Retrieved from https://www.toolbox.com/collaboration/teamcollaboration/question/what-are-the-common-barriersto-knowledge-management-in-organizations-090915/

Tywoniak, S. A. (2007). Knowledge in four deformation dimensions. Organization, 14(1), 53-76.

Ugoani, J. N. N. (2016). Employee turnover and productivity among small business entities in Nigeria. Independent Journal of Management \& Production,7(4), 1063-1082.

Ujwary-Gil, A. (2011). The analysis of barriers to knowledge management. In Business and non-profit organizations Facing Increased Competition abd Growing Customers' Demands, 20, 84.

Unnikrishnan, S., Iqbal, R., Singh, A., and Nimkar, I. M. (2015). Safety management practices in small and medium enterprises in India. Safety and Health at Work, 6(1), 46-55.

Usman, N. D., Inuwa, I. I., Kolawole, R. O., Kwari, J. M., and Didel, J. M. (2014). Evaluating the impact of housing delivery system on project performance within the building industry in Nigeria. Journal of Environmental Sciences and Resource Management, 6(1), 145-154.

von Krogh, G. (2002). The communal resource and information systems. Journal of Strategic Information Systems, 11(2), 85-107.

Whelton, M., Ballard, G., and Tommelein, I. D. (2002). A knowledge management framework for project definition. Journal of Information Technology in Construction, 7(13), 197-212.

Yip, K. (2011). Exploring barriers to knowledge sharing: A case study of a virtual community of practice in a Swedish multinational corporation. Published BSc. Thesis on informatics, Linneuniversitetet.

Zerbino, P., Aloini, D., Dulmin, R., and Mininno, V. (2018). Knowledge management in PCS-enabled ports: an assessment of the barriers. Knowledge Management Research \& Practice, 16 (4), 435-450.

Zhao, N. (2008). The minimum sample size in actor analysis. $\quad$ Retrieved from https://www.encorewiki.org/plugins/servlet/mobile\#co ntent/view/25657.

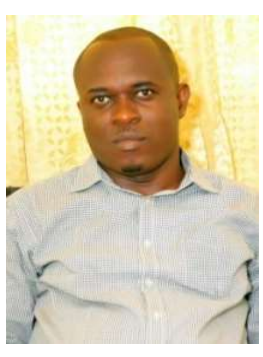

Samuel Ikechukwu Egwunatum had his degrees in Quantity Surveying from the Federal University of Technology, Akure, Nigeria, in 2014 specializing in Construction Economics. He had his compulsory paramilitary service in Nigeria in 2000. $\mathrm{He}$ started his lecturing career with Delta State Polytechnic, Ozoro, Nigeria, after a short stint in industry service, where he conceptualized the use of labourers productivity outputs to build cost models for estimating unit rate costs of construction work items and facilitating the cost modelling research group. He is currently a lecturer with the Federal University of Technology Owerri, Nigeria. He is a Corporate Member of The Nigerian Institute of Quantity Surveyors (NIQS), Association for the Advancement of cost engineering (AACE) and American Society of Professional Estimators (ASPE). He is a review editor to international journals and a consultant to the Delta State government of Nigeria on the Hydraform Mass Housing Project. He has to his credit, published one textbook in Germany on (Lost Labour Claims in Construction Projects: Principles and 2016) and a chapter contribution in the United Kingdom to the book Zero and Net Zero Buildings under the title: Economic Aspects of Zero Energy Buildings. He has over twenty-one published.

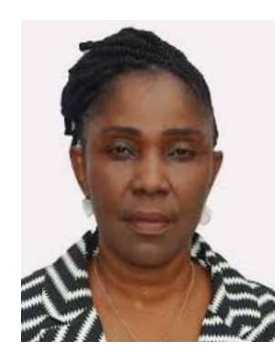

Oboreh, Justina C. (Ph.D.), had her degrees in management science. She is currently a lecturer and faculty member in the Department of Business Administration and Management with Delta State University, Abraka, Nigeria. She has many scholarly publications to her credit in reputable journals. She has served in different capacities in the department. She is an astute member of The Academy of Management Nigeria (TAMN), a Management Scholar at the Delta State University, Nigeria. Her area of interest is Administrative Management. She is a management exponent that strongly believes in qualitative and quantitative concepts of maximizing scarce resources to achieve optimal results. 